\title{
Preparation of Nickel-Alumina Composite Using the Metal-Coated Particles
}

\author{
Kyushu Univ., Eng. Junichi Hojo, Osamu Sagawa \\ Hideyoshi Kimura, Akio Kato
}

Junichi Hojo, Osamu Sagawa, Hideyoshi Kimura and Akio Kato: Preparation of NickelAlumina Composite Using the Metal-Coated Particles.

$\mathrm{Al}_{2} \mathrm{O}_{3}$ particles (mean diameter: $250 \mu \mathrm{m}$ ) were coated with fine $\mathrm{Ni}$ particles (mean diameter: $5 \mu \mathrm{m}$ ) by an agglomeration coating technique. The Ni content was $40-50 \mathrm{vol} \%$. The compact of the coated particles was sintered at a temperature of $1200^{\circ}-1500^{\circ} \mathrm{C}$. The use of the coated particles resulted in uniform dispersion of $\mathrm{Al}_{2} \mathrm{O}_{3}$ particles in Ni matrix. The pre-coating of $\mathrm{Al}_{2} \mathrm{O}_{3}$ particles with fine $W$ particles (mean diameter: $1 \mu \mathrm{m}$ ) was effective to improve the adhesion and wettability of $\mathrm{Ni}$ to $\mathrm{Al}_{2} \mathrm{O}_{3}$. Although the relative density of the sintered body was $70-80 \%$, the dense composite was produced by the infiltration of molten $\mathrm{Ni}$ into the porous sintered body.

( Received J anuary 12,1989)

\section{Introduction}

The uniform dispersion of ceramics particles in metal matrix and the high bonding strength between metal and ceramics are important to improve the mechanical property of metal-ceramics particulate composites. The use of metal-coated ceramics particles must be the most useful method to control the microstructure in the production of these composite materials. Hojo et al. " have developed an agglomeration coating technique to prepare metal-coated ceramics particles, in which ceramics particles were coated with fine metal particles.

In the present work, $\mathrm{Ni}-\mathrm{Al}_{2} \mathrm{O}_{3}$ composite was produced by the sintering of $\mathrm{Ni}$-coated $\mathrm{Al}_{2} \mathrm{O}_{3}$ particles prepared by the agglomeration process. The microstructure of sintered body and the effect of $W$ intermediate layer on $\mathrm{Ni}_{-}-\mathrm{Al}_{2} \mathrm{O}_{3}$ bonding were investigated. Furthermore, the infiltration of molten $\mathrm{Ni}$ into the porous $\mathrm{Ni}-\mathrm{Al}_{2} \mathrm{O}_{3}$ sintered body was carried out to produce the dense composite.

\section{Experiments}

Electrofused $\mathrm{Al}_{2} \mathrm{O}_{3}$ particles ( $N$ ikkei Kako Co.,Ltd) having the average size of 250 $\mu \mathrm{m}$ were coated with $\mathrm{Ni}$ particles having the average size of $5 \mu \mathrm{m}$ by an agglomeration coating technique" using polyethylene glycol as a binder, aluminium stearate as dispersant of $\mathrm{Ni}$ particles and a rotational tilted cylinder of acrylic resin as agglomeration apparatus. The $\mathrm{Ni}$ coating was repeated to increase $\mathrm{Ni}$ content after the heat treatment of the initial $\mathrm{Ni}$-coated $\mathrm{Al}_{2} \mathrm{O}_{3}$ particles at $1000^{\circ} \mathrm{C}$ in $\mathrm{H}_{2} . \mathrm{Al}_{2} \mathrm{O}_{3}$ particles were also coated with $W$ particles having the average size of $1.0 \mu \mathrm{m}$. After W-coated $\mathrm{Al}_{2} \mathrm{O}_{3}$ parti- 
cles were heat-treated at $1500^{\circ} \mathrm{C}$ in $\mathrm{H}_{2}$, they were coated with $\mathrm{Ni}$ particles. The mechanical mixture of $\mathrm{Al}_{2} \mathrm{O}_{3}$ and $\mathrm{Ni}$ particles was prepared using rotational tilted cylinder including alumina bowls to compare the microstructure of sintered body with that of metalcoated $\mathrm{Al}_{2} \mathrm{O}_{3}$ particles.

Powders were pressed into the pellets of $10 \mathrm{~mm}$ in diameter and $2-3 \mathrm{~mm}$ thick using a steel die at $3 \mathrm{t} / \mathrm{cm}^{2}$. The green density was about $70 \%$. The pellets were set in alumina container and heated for $4 \mathrm{~h}$ at $1200^{\circ}-1500^{\circ} \mathrm{C}$ in $\mathrm{H}_{2}$. A pellet of $\mathrm{Ni}$ particles was set on a porous sintered body and heated above the melting point of $\mathrm{Ni}$ in $\mathrm{H}_{2}$ to infiltrate molten $\mathrm{Ni}$ into the pores. The bulk density of the composite was determined from the size and weight. The microstructure was observed with a scanning electron microscope (SEM). The distribution of Welement was observed with an X-ray microanalyzer (XMA).

\section{Results and Discussion}

$3.1 \mathrm{Ni}$-coated $\mathrm{Al}_{2} \mathrm{O}_{3}$ particles and their sintered body

SEM photographs of original $\mathrm{Al}_{2} \mathrm{O}_{3}$ particles and $\mathrm{Ni}$-coated $\mathrm{Al}_{2} \mathrm{O}_{3}$ particles are shown in Photo.1. The $\mathrm{Ni}$ content was $44 \mathrm{vol} \%$ and the whole surface of $\mathrm{Al}_{2} \mathrm{O}_{3}$ particles was covered with fine $\mathrm{Ni}$ particles.
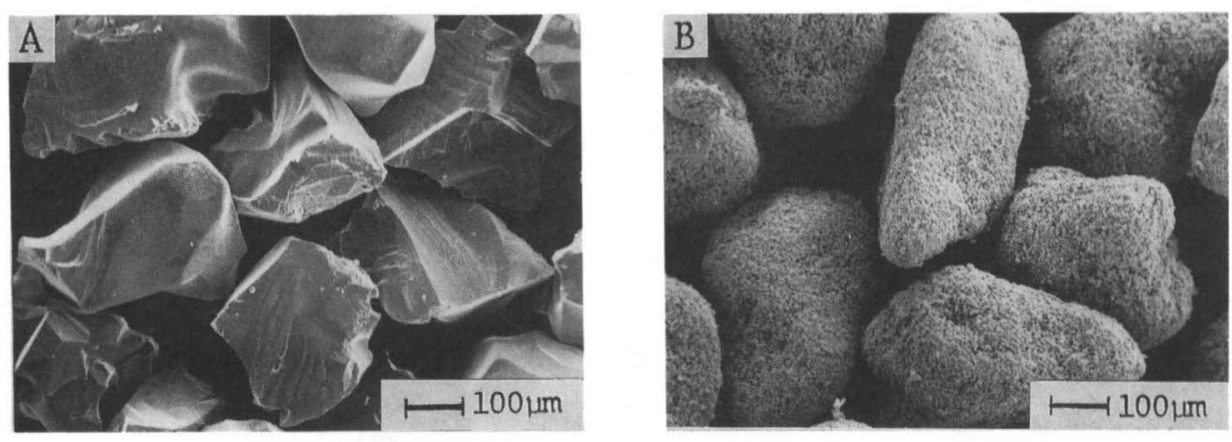

Photo.1 SEM for (A) $\mathrm{Al}_{2} \mathrm{O}_{3}$ particles and (B) Ni-coated $\mathrm{Al}_{2} \mathrm{O}_{3}$ particles ( $\mathrm{Ni}: 44 \mathrm{vol} \%$ ).
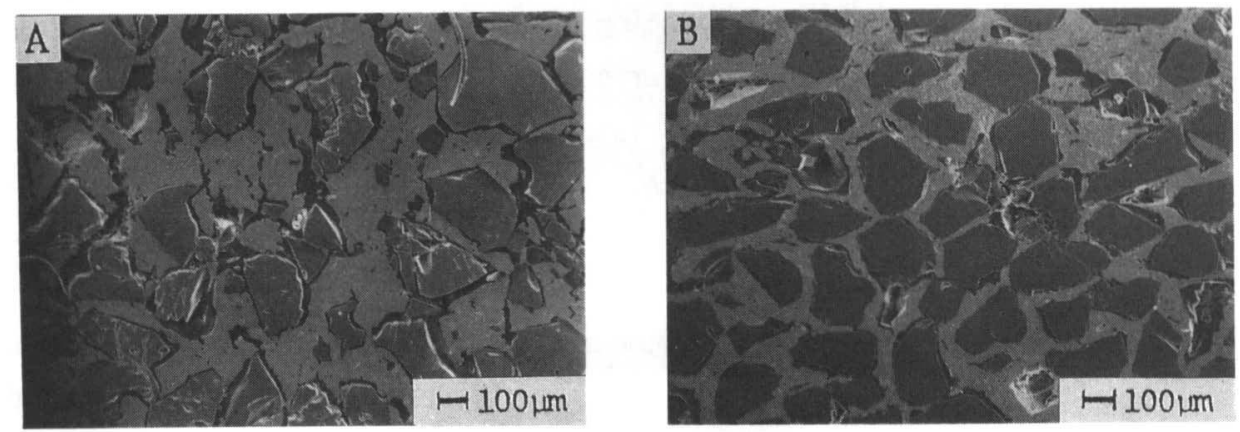

Photo.2 Section of sintered bodies of (A) mechanically-mixed powder $\left(\mathrm{Ni}_{\mathrm{Al}} \mathrm{Al}_{2} \mathrm{O}_{3}=45: 55 \mathrm{vol}\right.$ \%) and $(\mathrm{B}) \mathrm{Ni}$-coated $\mathrm{Al}_{2} \mathrm{O}_{3}$ particles $\left(\mathrm{Ni}: \mathrm{Al}_{2} \mathrm{O}_{3}=40: 60 \mathrm{vol} \%\right)$. Sintering temp.: $1400^{\circ} \mathrm{C}$. 
The microstructure of the sintered body obtained at $1400^{\circ} \mathrm{C}$ from $\mathrm{Ni}$-coated $\mathrm{Al}_{2} \mathrm{O}_{3}$ particles is compared with that obtained from the mechanical mixture of $\mathrm{Al}_{2} \mathrm{O}_{3}$ and $\mathrm{Ni}$ particles, as shown in Photo.2. When mechanically-mixed powder was used, $\mathrm{Al}_{2} \mathrm{O}_{3}$ particles were concentrated in parts and $\mathrm{Ni}$ phase was localized. On the other hand, $\mathrm{Ni}$-coated $\mathrm{Al}_{2} \mathrm{O}_{3}$ particles gave more uniform microstructure, in which $\mathrm{Al}_{2} \mathrm{O}_{3}$ particles were dispersed in $\mathrm{Ni}$ matrix. The relative density of these sintered bodies was about $80 \%$ and large voids were observed at $\mathrm{Ni} / \mathrm{Al}_{2} \mathrm{O}_{3}$ interface. The void enlarged with an increase in sintering temperature from $1200^{\circ}$ to $1400^{\circ} \mathrm{C}$. At $1500^{\circ} \mathrm{C}$, molten $\mathrm{Ni}$ was eliminated from the powder compact. $\mathrm{Ni}$ has a poor wettability and low bonding strength to $\mathrm{Al}_{2} \mathrm{O}_{3}{ }^{2.31}$.

3.2 Effect of $\mathrm{W}$ intermediate layer between $\mathrm{Ni}$ and $\mathrm{Al}_{2} \mathrm{O}_{3}$

The microstructure of the sintered body obtained at $1400^{\circ} \mathrm{C}$ from $\mathrm{Ni} / \mathrm{W}$-coated $\mathrm{Al}_{2} \mathrm{O}_{3}$ particles is compared with that obtained from $\mathrm{Ni}$-coated $\mathrm{Al}_{2} \mathrm{O}_{3}$ particles in Photo.3. When $\mathrm{Al}_{2} \mathrm{O}_{3}$ particles were pre-coated with $\mathrm{W}$ particles, $\mathrm{Ni}$ phase was intimately bound to $\mathrm{Al}_{2} \mathrm{O}_{3}$ particles. Even above the melting point of $\mathrm{Ni}$, molten $\mathrm{Ni}$ stayed in the sintered body. The distribution of $\mathrm{W}$ element is shown in Photo.4. It is found that $\mathrm{W}$ layer exists at $\mathrm{Ni}$ $/ \mathrm{Al}_{2} \mathrm{O}_{3}$ interface and a part of $\mathrm{W}$ dissolves in $\mathrm{Ni}$ matrix. $\mathrm{W}$ is known to be available for the metallization of alumina ceramics ${ }^{4}$. Since $W$ layer was heat-treated before $\mathrm{Ni}$ coating, $W$ layer seemed to form a strong bonding to $\mathrm{Al}_{2} \mathrm{O}_{3}$. When the mechanical mixture of $\mathrm{Ni}$, $W$ and $\mathrm{Al}_{2} \mathrm{O}_{3}$ particles was sintered at $1400^{\circ} \mathrm{C}$, large voids were observed at metal $/ \mathrm{Al}_{2} \mathrm{O}_{3}$ interface. It is important that $\mathrm{W}$ is localized between $\mathrm{Ni}$ and $\mathrm{Al}_{2} \mathrm{O}_{3}$.

The relative density of these sintered bodies was still low and large voids were observed in $\mathrm{Ni}$ matrix. The reason for the restricted densification may be that large $\mathrm{Al}_{2} \mathrm{O}_{3}$ particles are hardly rearranged during the sintering of $\mathrm{Ni}$ particles.

\subsection{Infiltration of molten $\mathrm{Ni}$ into the porous sintered body}

Molten $\mathrm{Ni}$ was infiltrated into the porous sintered body obtained from $\mathrm{Ni} / \mathrm{W}$-coated $\mathrm{Al}_{2} \mathrm{O}_{3}$ particles. The microstructure of the composite is shown in Photo.5. Large voids in the sintered body were filled up with molten $\mathrm{Ni}$. The reason for the easy penetration of
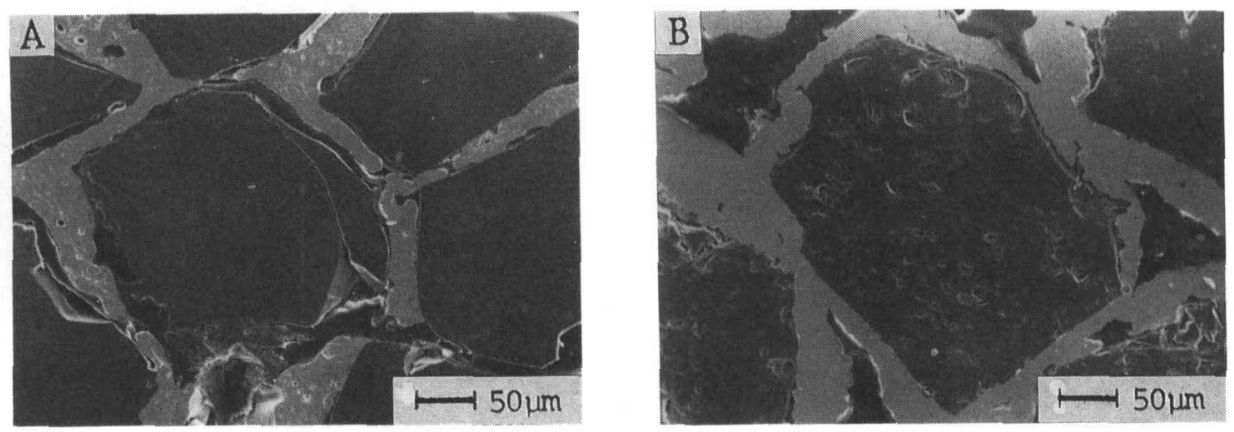

Photo.3 Section of sintered bodies of (A) Ni-coated $\mathrm{Al}_{2} \mathrm{O}_{3}$ particles $\left(\mathrm{Ni}_{\mathrm{Al}} \mathrm{Al}_{2} \mathrm{O}_{3}=40: 60 \mathrm{vol} \%\right.$ ) and $(B) \mathrm{Ni} / \mathrm{W}$-coated $\mathrm{Al}_{2} \mathrm{O}_{3}$ particles ( $\mathrm{Ni}: \mathrm{W}: \mathrm{Al}_{2} \mathrm{O}_{3}=39: 11: 50 \mathrm{vol} \%$ ). Sintering temp. $=1400^{\circ} \mathrm{C}$. 


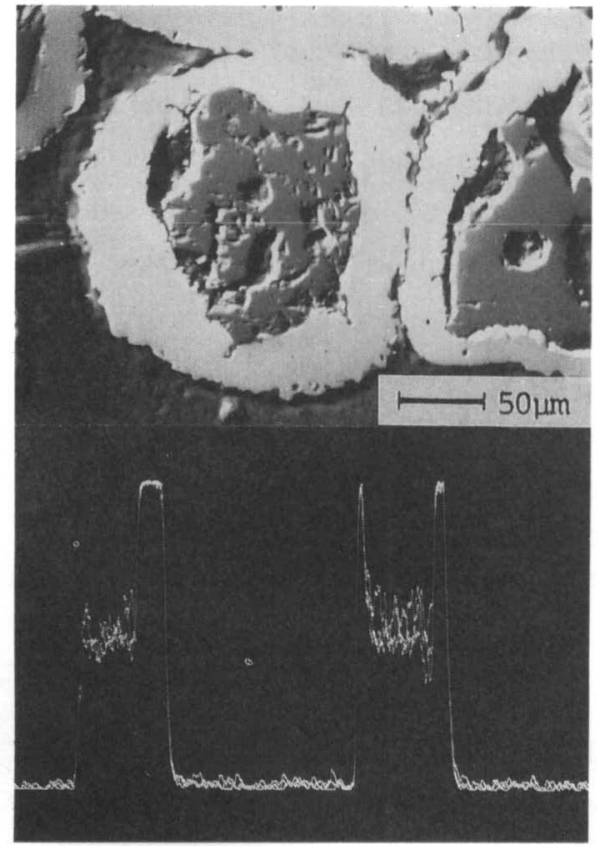

Photo.4 X-ray line profile of $W$ in the sintered body of $\mathrm{Ni} / \mathrm{W}$-coated $\mathrm{Al}_{2} \mathrm{O}_{3}$ particles. Sintering temp. $=1400^{\circ} \mathrm{C}$. molten $\mathrm{Ni}$ into pores may be that metal layer on $\mathrm{Al}_{2} \mathrm{O}_{3}$ particles acts as a guide for molten $\mathrm{Ni}$. The relative density of the composite was $97 \%$. The residual porosity may be assigned to closed pores included in the electrofused $\mathrm{Al}_{2} \mathrm{O}_{3}$ particles.

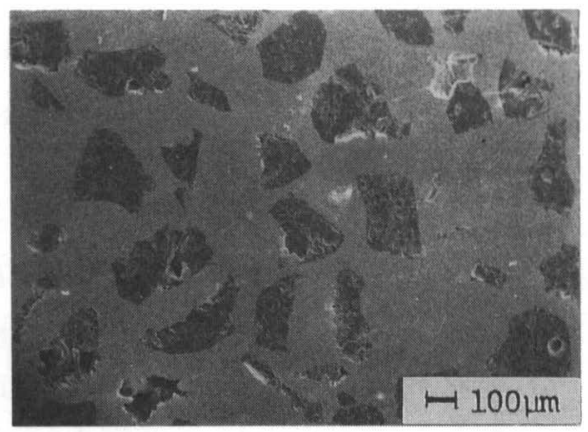

Photo.5 $\mathrm{Ni}$-infiltration into the sintered body of $\mathrm{Ni} / \mathrm{W}$-coated $\mathrm{Al}_{2} \mathrm{O}_{3}$ particles.

Inf il tration temp. $=1460^{\circ} \mathrm{C}$. $\mathrm{Ni}: \mathrm{W}: \mathrm{Al}_{2} \mathrm{O}_{3}=56: 8$ : 36 vol\%.

\section{Conclusion}

$\mathrm{Ni}-\mathrm{Al}_{2} \mathrm{O}_{3}$ particulate composite was produced by the sintering of the metal-coated particles prepared by an agglomeration coating technique. $\mathrm{Ni}$-coated $\mathrm{Al}_{2} \mathrm{O}_{3}$ particles gave a uniform microstructure, in which $\mathrm{Al}_{2} \mathrm{O}_{3}$ particles were dispersed in $\mathrm{Ni}$ matrix. The wettability and bonding strength of $\mathrm{Ni}$ to $\mathrm{Al}_{2} \mathrm{O}_{3}$ were significantly improved with the inclusion of $W$ intermediate layer. Although the sintered body was porous, the dense composite was obtained by the infiltration of molten $\mathrm{Ni}$ into the porous body.

Acknowledgement: This work was supported by a Grant-in-Aid for Scientific Research from Japanese Ministry of Education, Science and Culture (No.61550579).

\section{References}

1) J.Hojo, B.Champagne and S.Dallaire: Funtai Oyobi Funmatsuyakin, 36(4) (1989) in press.

2) Yu.V.Naidich, V.S.Zhuravlev and V.G.Chuprina: Poroshk. Metall., No.3(1974), 82.

3) R.M.Crispin and M.Nicholas: J. Mater. Sci., 11(1976), 17.

4) K.0tsuka, T.Usami and M.Sekihata: Am. Ceram. Soc. Bull., 60(1981), 540. 